\title{
Synthesis of G-quadruplex-targeting flexible macrocyclic molecules via click reactions
}

\author{
Qiang Zhang, Wei Tan, and Gu Yuan* \\ Beijing National Laboratory for Molecular Sciences, Key laboratory of Bioorganic Chemistry \\ and Molecular Engineering of Ministry of Education, Department of Chemical Biology, College \\ of Chemistry and Molecular Engineering, Peking University, Beijing 100871, China \\ E-mail: guyuan@pku.edu.cn
}

\begin{abstract}
Four flexible macrocycles, such as cTz (1), cTN (2), cPT (3), and cPTN (4), were efficiently synthesized through cyclodimerizing triazo-alkynyl-containing monomers via $\mathrm{Cu}(\mathrm{I})$-catalyzed click reactions with optimized conditions. The starting materials were pyrrole and triazole derivatives containing amine and carboxyl groups, followed by amide coupling to introduce the triazo and alkynyl groups to prepare the cyclization precursors. The electrospray ionization mass spectrometry (ESI-MS) results indicated that cTN (2) and cPT (3) showed the ability to bind with $c$-myb G-quadruplex. Therefore, cTN (2) and cPT (3) molecules might be potential leading compounds for anti-cancer drug discovery.
\end{abstract}

Keywords: Flexible macrocyclic molecules, click reaction, efficiently cyclization, G-quadruplex recognition

\section{Introduction}

DNA G-rich sequences widely exist in human genome and are potential to form G-quadruplex structures. $^{1,2}$ The G-quadruplex involved in the significant regions such as promoters and telomeres have been proven to play important roles in life process, including gene transcription and expression, cell division and apoptosis. ${ }^{1,3-10}$ GGA repeats sequences were reported to consist in the promoter of $c-m y b$ and show the ability to form a G-quadruplex structure. ${ }^{11-13}$ Further studies showed that Myc-associated zinc finger protein can bind to the G-quadruplex and repress $c$-myb promoter activity. ${ }^{14}$ Thus, the G-rich sequences in $c$-myb promoter region can act as a critical element to regulate the expression of the $c-m y b$. Furthermore, the small molecules that selectively bind with $c-m y b$ G-quadruplex and stabilize this structure are considered as potential anti-cancer drugs. 
The classic G-quadruplex macrocyclic ligands, such as telomestatin and porphyrins, stack on the terminal planar of G-quadruplex by $\pi-\pi$ interaction with high affinity. ${ }^{15-24}$ Recently, a novel flexible cyclic polyamide was synthesized and proven to selectively recognize the $c-m y b$ G-quadruplex in our laboratory. ${ }^{25}$ This flexible cyclic polyamide was efficiently cyclized by dimerizing two half-length precursors via amide-bonds formation. Herein, instead of amide coupling, we applied more efficient $\mathrm{Cu}(\mathrm{I})$-catalyzed click reaction for cyclization to obtain four flexible macrocyclic G-quadruplex ligands (Figure 1).
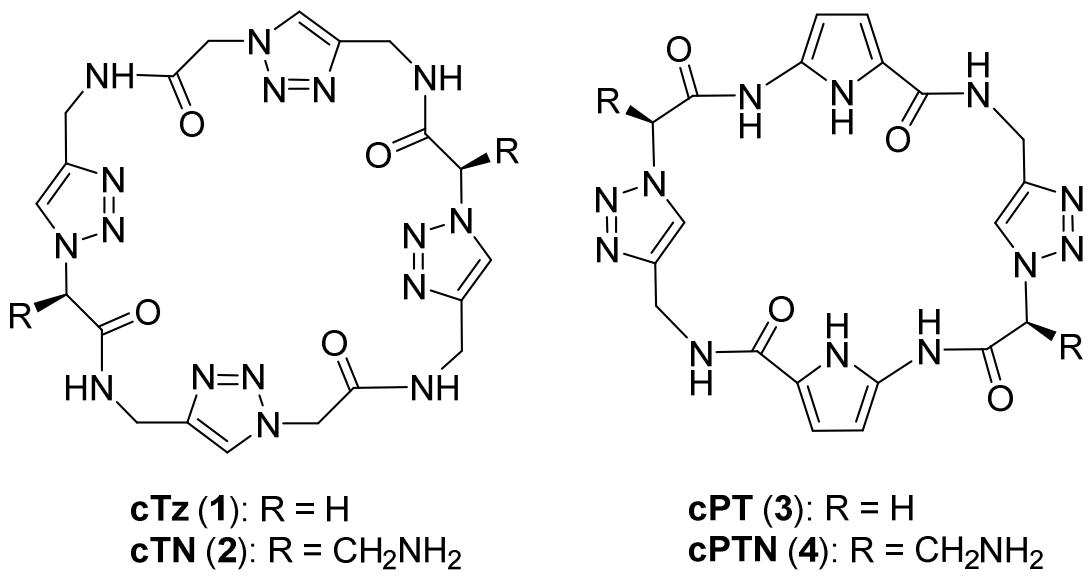

Figure 1. Structures of the macrocyclic molecules. cTz (1), cTN (2), cPT (3) and cPTN (4).

\section{Results and Discussion}

First, we optimized the $\mathrm{Cu}(\mathrm{I})$-catalyzed click reaction conditions using azidoacetic acid $\mathbf{5}$ and Boc-protected propynylamine $\mathbf{6}$ as model substrates, as shown in Table 1. In presence of TEMED ( $N, N, N^{\prime}, N^{\prime}$-tetramethylethylenediamine) as the ligand (100 mol\%), $\mathrm{CuCl}(20 \mathrm{~mol} \%)$ showed the higher catalytic activity than $\mathrm{CuI}$ and $\mathrm{CuBr}$ (entry 1-3). The reaction was promoted more effectively in THF than acetonitrile, and as the addition of water, the product yield increased to $71 \%$ when the THF / $\mathrm{H}_{2} \mathrm{O}$ ratio reached $5 / 1$ (entry 3-5). However, the further increasing amount of water suppressed the reaction due to the decreasing solubility of 6 (entry 6 , 7). Varieties of nitrogen-containing compounds (TEMED, DIMED ( $N, N$-Dimethylethanediamine), ethylenediamine, L-proline, 2, 6-lutidine, DIEA (ethyldiisopropylamine)) were evaluated to study the influence of ligands on the reaction (entry 3 , 8 -12). The results revealed bidentate ligand DIMED exhibited the best activity (yield 85\%, entry 8 ). The product yield was $23 \%$ even in the absence of ligand because formed trace triazole product promoted the reaction slightly (entry 13). In addition, more $\mathrm{CuCl}$ catalyst (50 mol\%) could raise the product yield obviously (95\%, entry 14$)$. 
Table 1. Optimization of click reaction conditions ${ }^{\text {a }}$

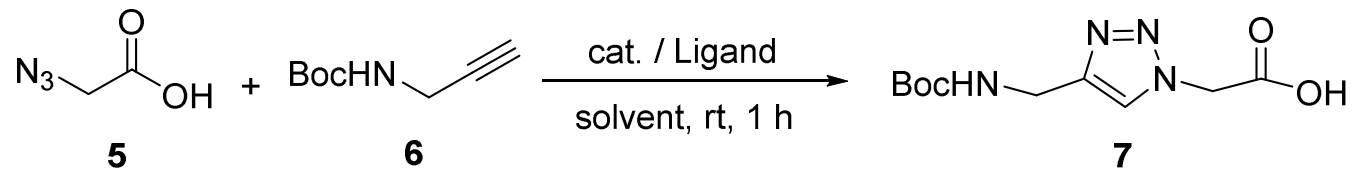

\begin{tabular}{|c|c|c|c|c|}
\hline Entry & Catalyst & Ligand & Solvent & Yield $(\%)$ \\
\hline 1 & $20 \mathrm{~mol} \% \mathrm{CuI}$ & $100 \mathrm{~mol} \%$ TEMED & $\mathrm{THF} / \mathrm{H}_{2} \mathrm{O} 5$ / 1 & 5 \\
\hline 2 & $20 \mathrm{~mol} \% \mathrm{CuBr}$ & $100 \mathrm{~mol} \%$ TEMED & $\mathrm{THF} / \mathrm{H}_{2} \mathrm{O} 5 / 1$ & 62 \\
\hline 3 & $20 \mathrm{~mol} \% \mathrm{CuCl}$ & $100 \mathrm{~mol} \%$ TEMED & $\mathrm{THF} / \mathrm{H}_{2} \mathrm{O} 5 / 1$ & 71 \\
\hline 4 & $20 \mathrm{~mol} \% \mathrm{CuCl}$ & 100 mol\% TEMED & $\mathrm{CH}_{3} \mathrm{CN}$ & 4 \\
\hline 5 & $20 \mathrm{~mol} \% \mathrm{CuCl}$ & $100 \mathrm{~mol} \%$ TEMED & $\mathrm{THF}$ & 66 \\
\hline 6 & $20 \mathrm{~mol} \% \mathrm{CuCl}$ & $100 \mathrm{~mol} \%$ TEMED & $\mathrm{THF} / \mathrm{H}_{2} \mathrm{O} 1 / 2$ & 57 \\
\hline 7 & $20 \mathrm{~mol} \% \mathrm{CuCl}$ & 100 mol\% TEMED & $\mathrm{H}_{2} \mathrm{O}$ & 62 \\
\hline 8 & $20 \mathrm{~mol} \% \mathrm{CuCl}$ & 100 mol\% DIMED & $\mathrm{THF} / \mathrm{H}_{2} \mathrm{O} 5$ / 1 & 85 \\
\hline 9 & $20 \mathrm{~mol} \% \mathrm{CuCl}$ & $100 \mathrm{~mol} \%$ ethylenediamine & $\mathrm{THF} / \mathrm{H}_{2} \mathrm{O} 5$ / 1 & 76 \\
\hline 10 & $20 \mathrm{~mol} \% \mathrm{CuCl}$ & 100 mol\% L-proline & $\mathrm{THF} / \mathrm{H}_{2} \mathrm{O} 5 / 1$ & 0 \\
\hline 11 & $20 \mathrm{~mol} \% \mathrm{CuCl}$ & 100 mol\% 2, 6-lutidine & $\mathrm{THF} / \mathrm{H}_{2} \mathrm{O} 5 / 1$ & 78 \\
\hline 12 & $20 \mathrm{~mol} \% \mathrm{CuCl}$ & 100 mol\% DIEA & $\mathrm{THF} / \mathrm{H}_{2} \mathrm{O} 5 / 1$ & 35 \\
\hline 13 & $20 \mathrm{~mol} \% \mathrm{CuCl}$ & no ligand & $\mathrm{THF} / \mathrm{H}_{2} \mathrm{O} 5 / 1$ & 23 \\
\hline 14 & $50 \mathrm{~mol} \% \mathrm{CuCl}$ & $100 \mathrm{~mol} \%$ DIMED & $\mathrm{THF} / \mathrm{H}_{2} \mathrm{O} 5 / 1$ & 95 \\
\hline
\end{tabular}

${ }^{a}$ Reaction conditions: azidoacetic acid $(5,13 \mathrm{mg}, 0.13 \mathrm{mmol})$ and Boc-protected propynylamine $(6,20 \mathrm{mg}, 0.13 \mathrm{mmol})$ in solvent $(1.0 \mathrm{~mL})$ at $\mathrm{rt}$ for $1 \mathrm{~h}$.

As shown in Scheme 1, propynylamine, and azidoacetic acid 5 or its derivative 9 were efficiently linked to the $\mathrm{C}$ - and N-terminal of $\mathbf{7}$ by amide bonds to afford cyclization precursors 10 and 11, respectively. In our case, uronium-based coupling reagent HBTU (2-(1H-benzotriazol-1-yl)-1,1,3,3-tetramethyluronium hexafluorophosphate) and phosphonium-based coupling reagent BOP (benzotriazole-1-yl-oxy-tris(dimethylamino)-phosphonium hexafluorophosphate) were utilized to activate the carboxylic acid of 7, and 5 or 9 in order to facilitate the amide-bond coupling reaction. The triazo-alkynyl-containing precursors were readily cyclized by the formation of two triazoles with high yields at the concentration of $2 \mathrm{mM}$ in the optimized click reaction condition. In addition, our starting material 12 for cPT (3) and cPTN (4) was obtained from pyrrole via five steps according to the procedures reported ${ }^{25,26}$. cPT (3) and cPTN (4) were also synthesized from triazole derivative 7 by the similar method (Scheme 2). 

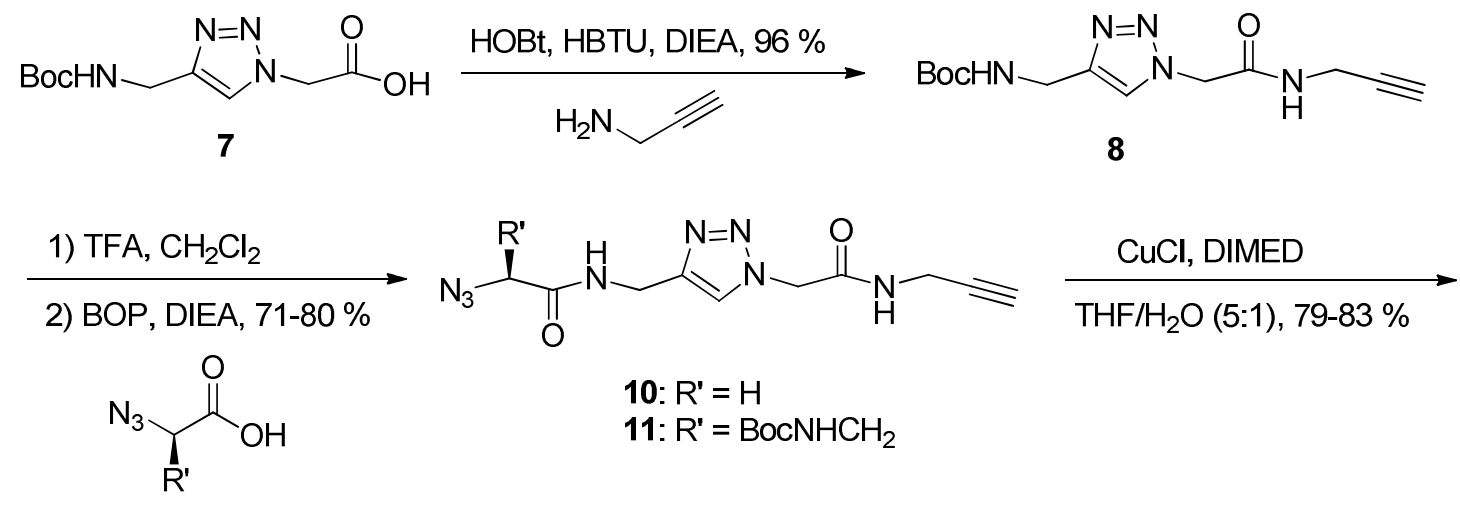

$$
\begin{aligned}
& \text { 5: } \mathrm{R}^{\prime}=\mathrm{H} \\
& \text { 9: } \mathrm{R}^{\prime}=\mathrm{BocNHCH}_{2}
\end{aligned}
$$

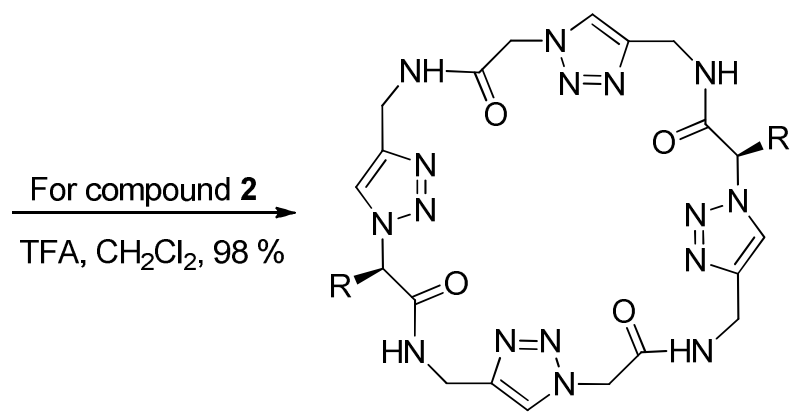

1: $\mathrm{R}=\mathrm{H}$
2: $\mathrm{R}=\mathrm{CH}_{2} \mathrm{NH}_{2}$

Scheme 1. Synthesis of macrocyclic molecules cTz (1) and cTN (2).

The binding affinity of compound 1-4 towards the $c$-myb G-quadruplex (Q1) was evaluated by ESI-MS. The mass spectra showed that as the molar ratio of ligand/Q1 was 4:1, the complex ion of Q1 with one cTN $\left([\mathrm{Q} 1+\mathbf{c T N}]^{5-}\right.$ ) at $\mathrm{m} / \mathrm{z} 1672.4$ appeared in the spectrum with an intensity of nearly $20 \%$ (Figure $2 \mathrm{a}$ ). For cPT, the complex ion $\left([\mathrm{Q} 1+\mathbf{c P T}]^{5-}\right.$ ) appeared at $\mathrm{m} / z 1649.5$ with an intensity of $50 \%$, and that of Q1 with two cPT ([Q1+2cPT $]^{5-}$ ) at $\mathrm{m} / z .1748 .0$ with an intensity of $10 \%$ (Figure $2 b$ ). The results indicated cTN (2) and cPT (3) exhibited the ability to bind with Q1 (Figure 2). To evaluate the binding affinity of cTN (2) and cPT (3) to Q1, the parameter $\mathrm{IR}_{\mathrm{a}}{ }^{27-30}$ was defined as the relative abundance ratio of bound ions $\left(\sum \operatorname{Ir}[\mathrm{Q} 1+\mathrm{nLigand}]^{5-}, \mathrm{n}=1,2\right)$ to that of both unbound and bound species ( $\sum \operatorname{Ir}[\mathrm{Q} 1]^{5-}+\sum \operatorname{Ir}[\mathrm{Q} 1+\mathrm{n} \text { Ligand }]^{5-}$, Equation 1). The $\mathrm{IR}_{\mathrm{a}}$ values were 0.15 and 0.29 for $\mathbf{c T N}(\mathbf{2})$ and $\mathbf{c P T}(\mathbf{3})$, respectively.

$$
\mathrm{IR}_{\mathrm{a}}=\frac{\mathrm{Ir}[\mathrm{Q} 1+\mathrm{nLigand}]^{5-}}{\operatorname{Ir}[\mathrm{Q} 1]^{5-}+\sum \operatorname{Ir}[\mathrm{Q} 1+\mathrm{nLigand}]^{5-}}
$$




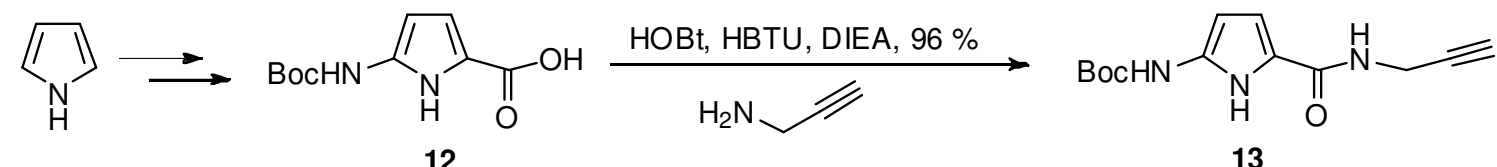

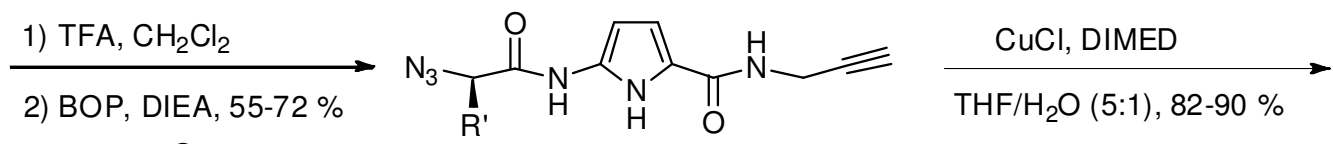<smiles>[R7]C([NH3+])C(=O)O</smiles>

5: $\mathrm{R}^{\prime}=\mathrm{H}$

9: $\mathrm{R}^{\prime}=\mathrm{BocNHCH}_{2}$

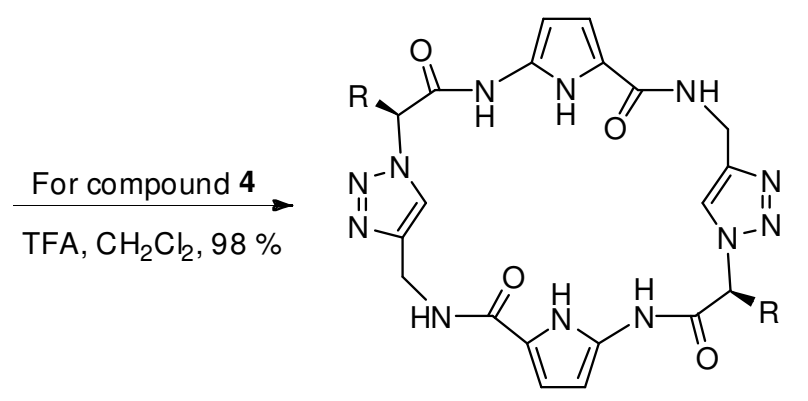

3: $\mathrm{R}=\mathrm{H}$

4: $\mathrm{R}=\mathrm{CH}_{2} \mathrm{NH}_{2}$

Scheme 2. Synthesis of macrocyclic molecules cPT (3) and cPTN (4).
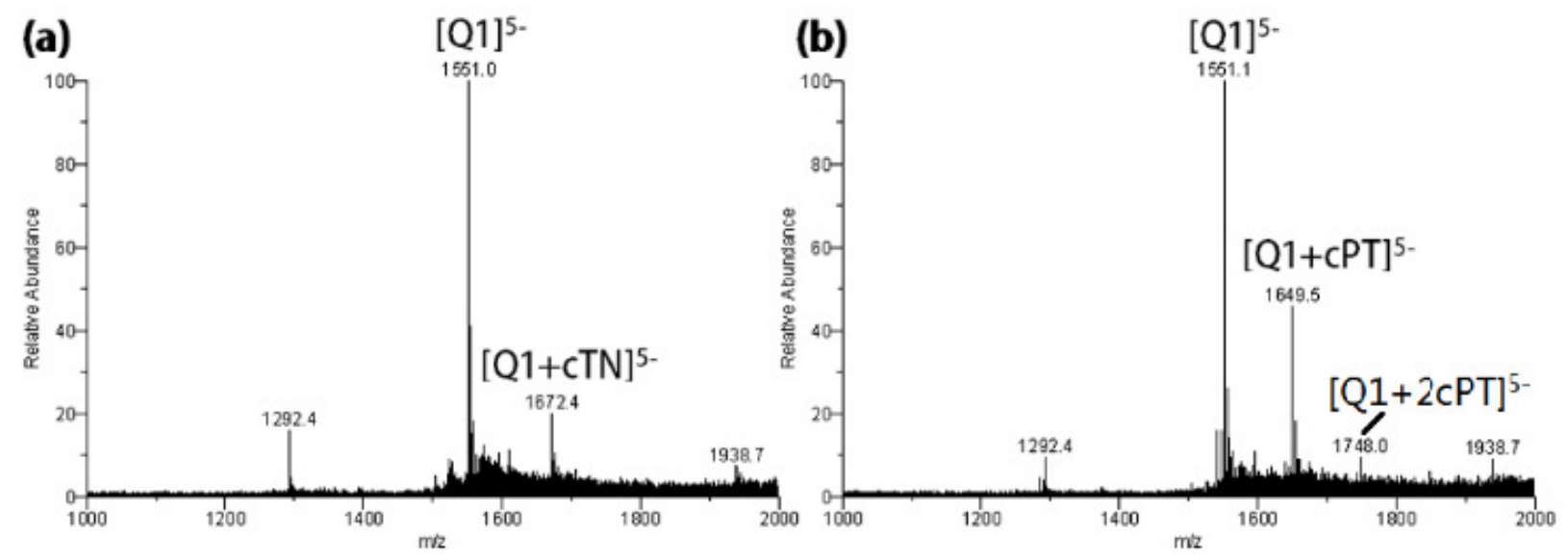

Figure 2. ESI mass spectra of the $c$-myb G-quadruplex (Q1) with $\mathbf{c T N}(\mathbf{2}, \mathrm{a})$ and $\mathbf{c P T}(\mathbf{3}, \mathrm{b})$ in $100 \mathrm{mM} \mathrm{NH}_{4} \mathrm{OAc}, 25 \% \mathrm{CH}_{3} \mathrm{OH}$. 


\section{Conclusions}

Macrocyclic molecules cTz (1), cTN (2), cPT (3), and cPTN (4) were synthesized conveniently from simple starting materials and cyclized via efficient click reaction with high yields. ESI-MS array demonstrated the binding affinities of cTN (2) and cPT (3) with $c$-myb G-quadruplex. cTN (2) and cPT (3) molecules have potential to be excellent G-quadruplex ligands with further derivatization.

\section{Experimental Section}

General. Low resolution mass (LRMS) spectra and ESI-MS binding array spectra were recorded on Thermo Finnigan SURVEYOR-LCQDECA (ESI-Ion Trap) mass spectrometer. High resolution mass (HRMS) spectra were recorded on Bruker APEX IV (ESI-FTICR) mass spectrometer. NMR spectra were recorded on Bruker $400 \mathrm{MHz}$ spectrometer. $1 \mathrm{H}$-Pyrrole, ethylenediamine, L-proline, sodium azide, and ethyl bromoacetate was purchased from Sinopharm Chemical Reagent Co., Ltd. Boc anhydride, 1-hydroxybenzotrizole (HOBt), HBTU, DIEA, BOP were purchased from Shanghai Medpep Co., Ltd. Propynylamine and DIMED were purchased from Energy Chemical Co., Ltd.. Trifluoroacetic acid (TFA), CuCl, CuBr, CuI, TEMED, and 2, 6-lutidine was purchased from J\&K Chemical Co., Ltd. (S)-isoserine was purchased from Beijing HWRK Chem Co., Ltd.

Azidoacetic acid (5). To a solution of ethyl bromoacetate $(20.0 \mathrm{~g}, 120 \mathrm{mmol})$ in DMF (20 mL) was added sodium azide $(12.5 \mathrm{~g}, 192 \mathrm{mmol})$ with stirring at $0{ }^{\circ} \mathrm{C}$. The mixture was allowed to warm to rt and stirred for $24 \mathrm{~h}$. Saturated sodium carbonate solution was added and the aqueous layer was extracted three times with $\mathrm{Et}_{2} \mathrm{O}$. The organic layer was combined and washed by saturated aqueous $\mathrm{NaHCO}_{3}$ and brine, dried over $\mathrm{Na}_{2} \mathrm{SO}_{4}$. The solvent was evaporated to obtain colorless liquid. Without further purification, $1 \mathrm{M} \mathrm{NaOH}(60 \mathrm{~mL})$ and methanol $(60 \mathrm{~mL})$ were added and stirred at $40{ }^{\circ} \mathrm{C}$. Methanol was evaporated after $5 \mathrm{~h}$. The $\mathrm{pH}$ of the remaining aqueous solution was adjusted about 2 by adding $2 \mathrm{M} \mathrm{HCl}$. The aqueous layer was extracted three times with $\mathrm{Et}_{2} \mathrm{O}$. The organic layer was combined and washed with brine, dried over $\mathrm{Na}_{2} \mathrm{SO}_{4}$. The solvent was evaporated to give 5 as a colorless liquid $(4.9 \mathrm{~g}, 48.5 \mathrm{mmol}, 81 \%) .{ }^{1} \mathrm{H} \mathrm{NMR}(400$ $\left.\mathrm{MHz}, \mathrm{CDCl}_{3}\right): \delta 6.97$ (s, $\left.1 \mathrm{H}\right), 3.95$ (s, $\left.2 \mathrm{H}\right) .{ }^{13} \mathrm{C} \mathrm{NMR}\left(100 \mathrm{MHz}, \mathrm{CDCl}_{3}\right): \delta 172.3,50.1$. LRMS (ESI-Ion Trap): $m / z$ calcd. for $\mathrm{C}_{2} \mathrm{H}_{2} \mathrm{~N}_{3} \mathrm{O}_{2}[M-\mathrm{H}]^{-} 100.0$ found 100.0.

tert-Butyl prop-2-yn-1-ylcarbamate (Boc-protected propynylamine, 6). To a solution of propynylamine $(5.5 \mathrm{~g}, 100 \mathrm{mmol})$ in EtOAc $(50 \mathrm{~mL})$ was added $\mathrm{Boc}_{2} \mathrm{O}(32.0 \mathrm{~g}, 147 \mathrm{mmol})$ with stirring at $0{ }^{\circ} \mathrm{C}$. The mixture was allowed to warm to $\mathrm{rt}$ and stirred overnight. The organic solution was washed by $1 \% \mathrm{HCl}$ solution, saturated aqueous $\mathrm{NaHCO}_{3}$, brine, dried over $\mathrm{Na}_{2} \mathrm{SO}_{4}$. The solvent was evaporated to give 6 as a yellow solid $(15.3 \mathrm{~g}, 99 \mathrm{mmol}, 99 \%) .{ }^{1} \mathrm{H}$ NMR (400 $\left.\mathrm{MHz}_{\mathrm{CDCl}}\right): \delta 4.75(\mathrm{~s}, 1 \mathrm{H}), 3.90\left(\mathrm{~d},{ }^{3} \mathrm{~J}_{(\mathrm{H}, \mathrm{H})} \quad 3.0 \mathrm{~Hz}, 2 \mathrm{H}\right), 2.21\left(\mathrm{t},{ }^{3} J_{(\mathrm{H}, \mathrm{H})} \quad 3.0 \mathrm{~Hz}, 1 \mathrm{H}\right), 1.44$ 
$(\mathrm{s}, 9 \mathrm{H}) .{ }^{13} \mathrm{C} \mathrm{NMR}\left(100 \mathrm{MHz}, \mathrm{CDCl}_{3}\right): \delta$ 155.2, 80.2, 71.4, 30.2, 28.2, 27.3. LRMS (ESI-Ion Trap): $m / z$ calcd. for $\mathrm{C}_{8} \mathrm{H}_{12} \mathrm{NO}_{2}[M-\mathrm{H}]^{-} 154.1$ found 154.0.

2-(4-(((tert-butoxycarbonyl)amino)methyl)-1H-1,2,3-triazol-1-yl)acetic acid (7). To a solution of 5 (1.3 g, $12.9 \mathrm{mmol})$ and $\mathbf{6}(2.0 \mathrm{~g}, 12.9 \mathrm{mmol})$ in THF $(10 \mathrm{~mL})$ was added water (2 $\mathrm{mL}), \mathrm{CuCl}(0.64 \mathrm{~g}, 6.5 \mathrm{mmol})$, and DIMED $(1.14 \mathrm{~g}, 12.9 \mathrm{mmol})$ sequentially with stirring at rt. 2 $\mathrm{M} \mathrm{HCl}$ solution $(2 \mathrm{~mL}$ ) and EtOAc were added after $1 \mathrm{~h}$. The organic layer was washed by $1 \%$ $\mathrm{HCl}$ solution and brine, dried over $\mathrm{Na}_{2} \mathrm{SO}_{4}$. The solvent was evaporated and the product was frozen to give 7 as a white solid $(3.0 \mathrm{~g}, 11.7 \mathrm{mmol}, 91 \%) .{ }^{1} \mathrm{H}$ NMR (400 MHz, acetone- $\left.d_{6}\right): \delta$ 11.91 (br, $1 \mathrm{H}), 7.96$ (s, $1 \mathrm{H}), 6.50$ (s, $1 \mathrm{H}), 5.33$ (s, $2 \mathrm{H}), 4.36$ (s, $2 \mathrm{H}), 1.44$ (s, $9 \mathrm{H}) .{ }^{13} \mathrm{C}$ NMR $\left(100 \mathrm{MHz}\right.$, acetone- $\left.d_{6}\right): \delta 168.8,156.8,124.9,82.0,79.1,51.2,36.7,28.2$. LRMS (ESI-Ion Trap): $m / z$ calcd. for $\mathrm{C}_{10} \mathrm{H}_{15} \mathrm{~N}_{4} \mathrm{O}_{4}[M-\mathrm{H}]^{-} 255.1$ found 255.0.

tert-Butyl ((1-(2-oxo-2-(prop-2-yn-1-ylamino)ethyl)-1H-1,2,3-triazol-4-yl)methyl)carbamate (8). To a solution of $7(1.00 \mathrm{~g}, 3.91 \mathrm{mmol})$, HOBt $(0.530 \mathrm{~g}, 3.93 \mathrm{mmol})$, and HBTU (2.20 $\mathrm{g}, 5.80 \mathrm{mmol})$ in DMF $(7 \mathrm{~mL})$ was added DIEA $(0.7 \mathrm{~mL}, 4 \mathrm{mmol})$ with stirring at rt. Propynylamine $(0.320 \mathrm{~g}, 5.82 \mathrm{mmol})$ was added after $15 \mathrm{~min}$. The mixture was stirred under $\mathrm{N}_{2}$ at $\mathrm{rt}$ overnight. The solution was added to EtOAc, followed by washing by $1 \% \mathrm{HCl}$ solution, saturated aqueous $\mathrm{NaHCO}_{3}$, and brine, dried over $\mathrm{Na}_{2} \mathrm{SO}_{4}$. The solvent was evaporated and the residue was purified by column chromatography on silica gel $\left(\mathrm{CHCl}_{3}: \mathrm{CH}_{3} \mathrm{OH} 15: 1-10: 1\right)$ to give 8 as a light yellow solid $(1.07 \mathrm{~g}, 3.65 \mathrm{mmol}, 93 \%) .{ }^{1} \mathrm{H}$ NMR (400 MHz, MeOD- $\left.d_{4}\right): \delta 7.88$ $(\mathrm{s}, 1 \mathrm{H}), 5.41(\mathrm{~s}, 2 \mathrm{H}), 4.32(\mathrm{~s}, 2 \mathrm{H}), 3.66\left(\mathrm{~d},{ }^{3} J_{(\mathrm{H}, \mathrm{H})} 3.0,2 \mathrm{H}\right), 2.63\left(\mathrm{t},{ }^{3} J_{(\mathrm{H}, \mathrm{H})} 3.0,2 \mathrm{H}\right), 1.43(\mathrm{~s}, 9$ H). ${ }^{13} \mathrm{C}$ NMR (100 MHz, MeOD- $\left.d_{4}\right): \delta$ 166.8, 147.5, 125.9, 82.8, 82.2, 72.3, 63.8, 42.9, 42.2, 31.3, 28.9. LRMS (ESI-Ion Trap): $m / z$ calcd. for $\mathrm{C}_{13} \mathrm{H}_{18} \mathrm{~N}_{5} \mathrm{O}_{3}[M-\mathrm{H}]^{-} 292.2$ found 292.1.

(R)-2-Azido-3-((tert-butoxycarbonyl)amino)propanoic acid) azidoacetic acid derivative (9). To a solution of $(S)$-isoserine $(5.00 \mathrm{~g}, 47.6 \mathrm{mmol})$ in ethanol $(200 \mathrm{~mL})$ was added hydrogen chloride gas with stirring at $0{ }^{\circ} \mathrm{C}$ for $5 \mathrm{~h}$. The mixture was allowed to warm to $\mathrm{rt}$ and stirred overnight. Ethanol was evaporated and EtOAc was added. $\mathrm{Boc}_{2} \mathrm{O}$ (15.0 g, $\left.68.8 \mathrm{mmol}\right)$ and triethylamine $(9.44 \mathrm{~g}, 93.5 \mathrm{mmol})$ were added and stirred at $0{ }^{\circ} \mathrm{C}$. The mixture was allowed to warm to $\mathrm{rt}$ and stirred overnight. The solvent was evaporated and the residue was washed with petroleum ether to obtain white solid intermediate. The intermediate compound was dissolved in $\mathrm{CH}_{2} \mathrm{Cl}_{2}(100 \mathrm{~mL})$ and triethylamine $(8.7 \mathrm{~g}, 86.3 \mathrm{mmol})$ was added. The mixture was treated dropwise with a solution of tosyl chloride $(9.8 \mathrm{~g}, 51.3 \mathrm{mmol})$ in $\mathrm{CH}_{2} \mathrm{Cl}_{2}(80 \mathrm{~mL})$. The mixture was allowed to warm to $\mathrm{rt}$ and stirred overnight. The organic solution was washed by $1 \% \mathrm{HCl}$ solution, saturated aqueous $\mathrm{NaHCO}_{3}$, and brine, dried over $\mathrm{Na}_{2} \mathrm{SO}_{4}$. The solvent was evaporated and the residue was dissolved in DMF $(75 \mathrm{~mL})$. Sodium azide $(7.0 \mathrm{~g}, 108 \mathrm{mmol})$ was added with stirring at rt. The reaction mixture was warmed to $60{ }^{\circ} \mathrm{C}$ and stirred overnight at this temperature. The mixture was then cooled to rt. saturated aqueous $\mathrm{NaHCO}_{3}$ was added and the aqueous layer was extracted three times with EtOAc. The organic layer was washed with brine, dried over $\mathrm{Na}_{2} \mathrm{SO}_{4}$. The solvent was evaporated and the residue was dissolved in methanol $(60 \mathrm{~mL}) .1 \mathrm{M}$ $\mathrm{NaOH}(60 \mathrm{~mL})$ was added with stirring at $40{ }^{\circ} \mathrm{C}$. Methanol was evaporated after $5 \mathrm{~h}$. The aqueous layer was washed twice with $\mathrm{Et}_{2} \mathrm{O}$. The $\mathrm{pH}$ of the remaining aqueous solution was 
adjusted about 2 by adding $2 \mathrm{M} \mathrm{HCl}$. The aqueous layer was extracted three times with $\mathrm{Et}_{2} \mathrm{O}$. The organic layer was combined and washed with brine, dried over $\mathrm{Na}_{2} \mathrm{SO}_{4}$. The solvent was evaporated to give 9 as a light yellow solid (7.1 g, $30.9 \mathrm{mmol}, 65 \%) .{ }^{1} \mathrm{H} \mathrm{NMR}(400 \mathrm{MHz}$, $\left.\mathrm{CDCl}_{3}\right): \delta 7.80\left(\mathrm{~d},{ }^{3} J_{(\mathrm{H}, \mathrm{H})} 7.8 \mathrm{~Hz}, 1 \mathrm{H}\right), 7.18(\mathrm{~s}, 1 \mathrm{H}), 4.17(\mathrm{~m}, 1 \mathrm{H}), 3.60(\mathrm{~m}, 1 \mathrm{H}), 3.42(\mathrm{~m}, 1$ $\mathrm{H}), 1.44(\mathrm{~s}, 9 \mathrm{H}) .{ }^{13} \mathrm{C} \mathrm{NMR}\left(100 \mathrm{MHz}, \mathrm{CDCl}_{3}\right): \delta 176.5,171.9,80.7,61.5,41.7,28.3$. LRMS (ESI-Ion Trap): $m / z$ calcd. for $\mathrm{C}_{8} \mathrm{H}_{13} \mathrm{~N}_{4} \mathrm{O}_{4}[M-\mathrm{H}]^{-} 229.1$ found 229.0.

2-Azido- $N$-((1-(2-oxo-2-(prop-2-yn-1-ylamino)ethyl)-1H-1,2,3-triazol-4-yl)methyl)acetamide (10). To a suspension of $\mathbf{8}(0.250 \mathrm{~g}, 0.853 \mathrm{mmol})$ in $\mathrm{CH}_{2} \mathrm{Cl}_{2}(4 \mathrm{~mL})$ was added the same volume of TFA ( $4 \mathrm{~mL}$ ) under $\mathrm{N}_{2}$. After being stirred at $\mathrm{rt}$ for $1 \mathrm{~h}$, the solvent was evaporated to give a yellow solid and added to the mixture of $5(0.130 \mathrm{~g}, 1.29 \mathrm{mmol})$, BOP $(0.860 \mathrm{~g}, 1.94 \mathrm{mmol})$, and DIEA $(0.5 \mathrm{~mL}, 3 \mathrm{mmol})$ in DMF $(5 \mathrm{~mL})$ was stirred under $\mathrm{N}_{2}$ at $\mathrm{rt}$ overnight. The solution was added to EtOAc, followed by washing by $1 \% \mathrm{HCl}$ solution, saturated aqueous $\mathrm{NaHCO}_{3}$, and brine, dried over $\mathrm{Na}_{2} \mathrm{SO}_{4}$. The solvent was evaporated and the residue was purified by column chromatography on silica gel $\left(\mathrm{CHCl}_{3}: \mathrm{CH}_{3} \mathrm{OH}\right.$ 15: $\left.1-10: 1\right)$ to give $\mathbf{1 0}$ as a light yellow solid (0.188 g, $0.681 \mathrm{mmol}, 80 \%) .{ }^{1} \mathrm{H}$ NMR (400 MHz, acetone- $\left.d_{6}\right): \delta 7.91(\mathrm{~s}, 1 \mathrm{H}), 5.32(\mathrm{~s}, 2 \mathrm{H}), 4.01$ $(\mathrm{s}, 2 \mathrm{H}), 3.94(\mathrm{~s}, 2 \mathrm{H}), 3.75(\mathrm{~s}, 2 \mathrm{H}), 2.62$ (s, $1 \mathrm{H}) .{ }^{13} \mathrm{C}$ NMR (100 MHz, acetone- $\left.d_{6}\right): \delta$ 166.8, 148.0, 126.1, 82.8, 82.2, 63.8, 51.2, 42.9, 42.2, 31.3. LRMS (ESI-Ion Trap): $m / z$ calcd. for $\mathrm{C}_{10} \mathrm{H}_{11} \mathrm{~N}_{8} \mathrm{O}_{2}[M-\mathrm{H}]^{-} 275.1$ found 275.0 .

tert-Butyl (S)-(2-azido-3-oxo-3-(((1-(2-oxo-2-(prop-2-yn-1-ylamino)ethyl)-1H-1,2,3-triazol4-yl)methyl)amino)propyl)carbamate (11). The synthesis of 11 was similar to that of $\mathbf{1 0} 11$ was a light yellow solid $(0.245 \mathrm{~g}, 0.605 \mathrm{mmol}, 71 \%) .{ }^{1} \mathrm{H} \mathrm{NMR}\left(400 \mathrm{MHz}\right.$, acetone- $\left.d_{6}\right): \delta 7.90(\mathrm{~s}$, $1 \mathrm{H}), 5.33$ (s, $2 \mathrm{H}), 4.16$ (s, $2 \mathrm{H}), 4.14$ (s, $1 \mathrm{H}), 4.36$ (s, $2 \mathrm{H}), 3.64$ (m, $1 \mathrm{H}), 3.44$ (m, $1 \mathrm{H}), 2.64$ (s $1 \mathrm{H}), 1.41(\mathrm{~s}, 9 \mathrm{H}) .{ }^{13} \mathrm{C}$ NMR $\left(100 \mathrm{MHz}\right.$, acetone- $\left.d_{6}\right): \delta 165.8,161.2,148.2,126.2,156.1,81.7$, 79.3, 71.8, 63.3, 51.2, 43.2, 31.3, 28.8, 28.6. LRMS (ESI-Ion Trap): $m / z$ calcd. $\mathrm{C}_{16} \mathrm{H}_{22} \mathrm{~N}_{9} \mathrm{O}_{4}$ $[M-\mathrm{H}]^{-} 404.2$ found 404.1 .

cTz (1). To a solution of $\mathbf{1 0}(0.100 \mathrm{~g}, 0.362 \mathrm{mmol})$ in THF $(150 \mathrm{~mL})$ was added water $(30 \mathrm{~mL})$, $\mathrm{CuCl}$ (18 mg, $0.182 \mathrm{mmol}$ ), and DIMED (32 mg, $0.364 \mathrm{mmol}$ ) sequentially with stirring at $\mathrm{rt}$. The concentration of substrate $\mathbf{1 0}$ was $2 \mathrm{mM}$. THF was evaporated after $1 \mathrm{~d}$. The precipitate was collected by filtration and washed by proper amount of methanol to give $\mathbf{1}$ as a light yellow solid $(0.083 \mathrm{~g}, 0.150 \mathrm{mmol}, 83 \%)$ and showed very poor solubility in common organic solvents and water. LRMS (ESI-Ion Trap): $m / z$ calcd. $\mathrm{C}_{20} \mathrm{H}_{23} \mathrm{~N}_{16} \mathrm{O}_{4}[M-\mathrm{H}]^{-} 551.2$ found 551.1.

cTN (2). The cyclization of $\mathbf{2}$ was similar to that of $\mathbf{1}$. The precipitate was collected by filtration and washed by a small amount of methanol. The residue was added the solution of TFA $/ \mathrm{CH}_{2} \mathrm{Cl}_{2}$ $(1: 1, \mathrm{v} / \mathrm{v}, 4 \mathrm{~mL})$ with stirring at $\mathrm{rt}$. The solvent was evaporated and added saturated solution of $\mathrm{HCl}$ in EtOAc, followed by adding $\mathrm{Et}_{2} \mathrm{O}$. The precipitate was collected by filtration to give the 2 hydrochloride salt as a light yellow solid $(0.097 \mathrm{~g}, 0.142 \mathrm{mmol}, 77 \%) .{ }^{1} \mathrm{H}$ NMR (400 MHz, DMSO-d $\left.)_{6}\right): \delta 9.47(\mathrm{~s}, 2 \mathrm{H}), 9.32(\mathrm{~s}, 2 \mathrm{H}), 8.37(\mathrm{~s}, 4 \mathrm{H}), 7.62(\mathrm{~s}, 2 \mathrm{H}), 7.48(\mathrm{~s}, 2 \mathrm{H}), 5.53\left(\mathrm{~s},{ }^{3} J\right.$ $(\mathrm{H}, \mathrm{H}) \quad 5.5,2 \mathrm{H}), 4.87(\mathrm{~s}, 4 \mathrm{H}), 4.61(\mathrm{~m}, 2 \mathrm{H}), 4.32(\mathrm{~s}, 4 \mathrm{H}), 3.96(\mathrm{~m}, 2 \mathrm{H}) .{ }^{13} \mathrm{C} \mathrm{NMR}(100 \mathrm{MHz}$, DMSO- $\left.d_{6}\right): \delta 165.4,164.9,145.9,121.7,121.5,60.0,54.1,38.0,34.7,34.4$. HRMS (ESI-FTICR): $m / z$ calcd. $\mathrm{C}_{22} \mathrm{H}_{31} \mathrm{~N}_{18} \mathrm{O}_{4}[M+\mathrm{H}]^{+} 611.2776$ found 611.2782. 
tert-Butyl (5-(prop-2-yn-1-ylcarbamoyl)-1H-pyrrol-2-yl)carbamate (13). The synthesis of 13 was similar to that of $\mathbf{8} .13$ was a light yellow solid $(1.12 \mathrm{~g}, 4.26 \mathrm{mmol}, 96 \%)$. ${ }^{1} \mathrm{H}$ NMR (400 MHz, DMSO- $\left.d_{6}\right): \delta 11.10(\mathrm{~s}, 1 \mathrm{H}), 9.01(\mathrm{~s}, 1 \mathrm{H}), 8.42\left(\mathrm{t},{ }^{3} J_{(\mathrm{H}, \mathrm{H})} \quad 8.0 \mathrm{~Hz}, 1 \mathrm{H}\right), 6.81(\mathrm{~s}, 1 \mathrm{H}), 6.70$ $(\mathrm{s}, 1 \mathrm{H}), 3.96(\mathrm{~s}, 2 \mathrm{H}), 3.09$ (s, $1 \mathrm{H}), 1.44(\mathrm{~s}, 9 \mathrm{H}) .{ }^{13} \mathrm{C}$ NMR (100 MHz, DMSO- $\left.d_{6}\right): \delta$ 171.6, 163.7, 155.7, 125.7, 124.1, 113.2, 104.0, 80.4, 30.2, 28.2, 27.3. LRMS (ESI-Ion Trap): $\mathrm{m} / z$ calcd. $\mathrm{C}_{13} \mathrm{H}_{16} \mathrm{~N}_{3} \mathrm{O}_{3}[M-\mathrm{H}]^{-} 262.1$ found 261.9 .

5-(2-Azidoacetamido)- $\boldsymbol{N}$-(prop-2-yn-1-yl)-1H-pyrrole-2-carboxamide (14). The synthesis of 14 was similar to that of 10. 14 was a light yellow solid $(0.337 \mathrm{~g}, 1.37 \mathrm{mmol}, 72 \%)$. ${ }^{1} \mathrm{H}$ NMR $\left(400 \mathrm{MHz}, \mathrm{MeOD}-d_{4}\right): \delta 7.26\left(\mathrm{~d},{ }^{3} J_{(\mathrm{H}, \mathrm{H})} \quad 7.2,1 \mathrm{H}\right), 6.83\left(\mathrm{~d},{ }^{3} J_{(\mathrm{H}, \mathrm{H})} \quad 7.2,1 \mathrm{H}\right), 4.09\left(\mathrm{~d},{ }^{3} J_{(\mathrm{H}, \mathrm{H})}\right.$ 4.1, $2 \mathrm{H}), 3.99(\mathrm{~s}, 2 \mathrm{H}), 2.58\left(\mathrm{t},{ }^{3} J_{(\mathrm{H}, \mathrm{H})} \quad 4.1,1 \mathrm{H}\right) .{ }^{13} \mathrm{C}$ NMR $\left(100 \mathrm{MHz}, \mathrm{MeOD}-d_{4}\right): \delta 167.2$, 162.9, 124.4, 114.6, 104.3, 81.1, 72.0, 53.1, 29.4, 24.3. LRMS (ESI-Ion Trap): $\mathrm{m} / \mathrm{z}$ calcd. $\mathrm{C}_{10} \mathrm{H}_{9} \mathrm{~N}_{6} \mathrm{O}_{2}[M-\mathrm{H}]^{-} 245.1$ found 245.0 .

tert-Butyl $(R)$-(2-azido-3-oxo-3-((5-(prop-2-yn-1-ylcarbamoyl)-1H-pyrrol-2-yl)amino)propyl)carbamate (15). The synthesis of 15 was similar to that of 11. 15 was a light yellow solid (0.390 g, $1.04 \mathrm{mmol}, 55 \%)$. ${ }^{1} \mathrm{H}$ NMR (400 MHz, acetone- $\left.d_{6}\right): \delta 10.62$ (s, $\left.1 \mathrm{H}\right), 9.45$ (s, 1 H), 7.75 (s, $1 \mathrm{H}), 7.38(\mathrm{~s}, 1 \mathrm{H}), 6.92(\mathrm{~s}, 1 \mathrm{H}), 6.38(\mathrm{~s}, 1 \mathrm{H}), 4.14(\mathrm{~s}, 2 \mathrm{H}), 4.13$ (s, $1 \mathrm{H}), 3.64$ (m, 1 $\mathrm{H}), 3.44(\mathrm{~m}, 1 \mathrm{H}), 2.64(\mathrm{~s} 1 \mathrm{H}), 1.41(\mathrm{~s}, 9 \mathrm{H}) .{ }^{13} \mathrm{C}$ NMR $\left(100 \mathrm{MHz}\right.$, acetone- $\left.d_{6}\right): \delta 165.8,161.2$, 156.8, 124.6, 124.5, 113.4, 102.7, 81.7, 79.3, 71.8, 63.3, 43.2, 28.8, 28.6. LRMS (ESI-Ion Trap): $\mathrm{m} / z$ calcd. $\mathrm{C}_{16} \mathrm{H}_{20} \mathrm{~N}_{7} \mathrm{O}_{4}[M-\mathrm{H}]^{-} 374.2$ found 374.0 .

cPT (3). The synthesis of $\mathbf{3}$ was similar to that of $\mathbf{1} . \mathbf{3}$ was a tan solid $(0.090 \mathrm{~g}, 0.183 \mathrm{mmol}$, 90\%). ${ }^{1} \mathrm{H}$ NMR (400 MHz, DMSO- $\left.d_{6}\right): \delta 11.44$ (s, $2 \mathrm{H}$ ), 9.98 (s, $2 \mathrm{H}$ ), 8.28 (s, $2 \mathrm{H}$ ), 7.92 (s, 2 $\mathrm{H}), 7.01(\mathrm{~s}, 2 \mathrm{H}), 6.91(\mathrm{~s}, 2 \mathrm{H}), 5.13(\mathrm{~s}, 4 \mathrm{H}), 4.49(\mathrm{~s}, 4 \mathrm{H}) \cdot{ }^{13} \mathrm{C}$ NMR $\left(100 \mathrm{MHz}, \mathrm{DMSO}-d_{6}\right): \delta$ 162.3, 159.9, 156.5, 123.6, 123.4, 122.9, 111.6, 103.0, 53.1, 34.2. HRMS (ESI-FTICR): $\mathrm{m} / z$ calcd. $\mathrm{C}_{20} \mathrm{H}_{21} \mathrm{~N}_{12} \mathrm{O}_{4}[M+\mathrm{H}]^{+} 493.1809$ found 493.1791 .

cPTN (4). The synthesis of $\mathbf{4}$ was similar to that of $\mathbf{2 .} \mathbf{4}$ hydrochloride salt was a yellow solid (0.100 g, $0.161 \mathrm{mmol}, 81 \%) .{ }^{1} \mathrm{H}$ NMR (400 MHz, DMSO-d $)$ : $\delta 11.37$ (s, $\left.2 \mathrm{H}\right), 10.95$ (s, $2 \mathrm{H}$ ), $8.74(\mathrm{~s}, 2 \mathrm{H}), 8.34$ (s, $2 \mathrm{H}), 8.18$ (s, $2 \mathrm{H}), 7.13$ (s, $2 \mathrm{H}), 6.81(\mathrm{~s}, 2 \mathrm{H}), 5.78$ (s, $4 \mathrm{H}), 4.47$ (s, $4 \mathrm{H})$, $3.66(\mathrm{~m}, 2 \mathrm{H}), 3.39(\mathrm{~m}, 2 \mathrm{H}) .{ }^{13} \mathrm{C}$ NMR (100 MHz, DMSO- $\left.d_{6}\right): \delta 161.5,160.2,123.5,122.8$, 122.6, 112.1, 102.5, 65.0, 60.0, 56.0, 34.1. HRMS (ESI-FTICR): $m / z$ calcd. $\mathrm{C}_{22} \mathrm{H}_{27} \mathrm{~N}_{14} \mathrm{O}_{4}$ $[M+\mathrm{H}]^{+} 551.2340$ found 551.2342.

ESI-MS binding array. The oligonucleotide 5' $-(\mathrm{GGA})_{8}-3^{\prime}$ 'representing the G-rich sequence in the $c$-myb promoter (Q1) was synthesized by Sangon Biotech Co., Ltd. (China) and further desalted using Microcon filters (Amicon, Beverly, MA, USA) for purification. ESI mass spectra were collected using Finnigan LCQ Deca XP Plus ion-trap mass spectrometer (Thermo Finnigan, San Jose, CA). The DNA sample was diluted in $100 \mathrm{mM} \mathrm{NH}_{4} \mathrm{OAc}$, 25\% (volume fraction) methanol solution. Negative ion mode was used with a spray voltage of $2.7 \mathrm{kV}$ and a capillary temperature of $120^{\circ} \mathrm{C}$. 


\section{Acknowledgements}

Project supported by National Basic Research Program of China (973 Program)

(2012CB720600, 2012CB720601) and National Natural Science Foundation of China (21372021).

\section{References}

1. Todd, A. K.; Johnston, M.; Neidle, S. Nucleic. Acids. Res. 2005, 33, 2901-2907. http://dx.doi.org/10.1093/nar/gki553 PMid:15914666 PMCid:PMC1140077

2. Davis, J. T. Angew. Chem. Int. Edit. 2004, 43, 668-698.

http://dx.doi.org/10.1002/anie.200300589

PMid:14755695

3. Fletcher, T. M.; Sun, D. K.; Salazar, M.; Hurley, L. H. Biochemistry-us. 1998, 37, 5536-5541.

http://dx.doi.org/10.1021/bi972681p

PMid:9548937

4. Henderson, E.; Hardin, C. C.; Walk, S. K.; Tinoco, I.; Blackburn, E. H. Cell 1987, 51, 899-908.

http://dx.doi.org/10.1016/0092-8674(87)90577-0

5. Sen, D.; Gilbert, W. Nature 1988, 334, 364-366.

http://dx.doi.org/10.1038/334364a0

PMid:3393228

6. Sun, D. Y.; Thompson, B.; Cathers, B. E.; Salazar, M.; Kerwin, S. M.; Trent, J. O.; Jenkins, T. C.; Neidle, S.; Hurley, L. H. J. Med. Chem. 1997, 40, 2113-2116.

http://dx.doi.org/10.1021/jm970199z

PMid:9216827

7. Oh, I. H.; Reddy, E. P. Oncogene 1999, 18, 3017-3033.

http://dx.doi.org/10.1038/sj.onc.1202839

PMid:10378697

8. Griffin, C. A.; Baylin, S. B. Cancer Res. 1985, 45, 272-275.

PMid:2578097

9. Ramsay, R. G.; Thompson, M. A.; Hayman, J. A.; Reid, G.; Gonda, T. J.; Whitehead, R. H. Cell Growth Differ. 1992, 3, 723-730.

PMid:1445802

10. Todokoro, K.; Watson, R. J.; Higo, H.; Amanuma, H.; Kuramochi, S.; Yanagisawa, H.; Ikawa, Y. Proc. Natl. Acad. Sci. U. S. A 1988, 85, 8900-8904. http://dx.doi.org/10.1073/pnas.85.23.8900 
11. Kettani, A.; Gorin, A.; Majumdar, A.; Hermann, T.; Skripkin, E.; Zhao, H.; Jones, R.; Patel, D. J. J. Mol. Biol. 2000, 297, 627-644.

http://dx.doi.org/10.1006/jmbi.2000.3524

PMid:10731417

12. Matsugami, A.; Ouhashi, K.; Kanagawa, M.; Liu, H.; Kanagawa, S.; Uesugi, S.; Katahira, M. J. Mol. Biol. 2001, 313, 255-269.

http://dx.doi.org/10.1006/jmbi.2001.5047

PMid:11800555

13. Matsugami, A.; Okuizumi, T.; Uesugi, S.; Katahira, M. J. Biol. Chem. 2003, 278, 28147-28153.

http://dx.doi.org/10.1074/jbc.M303694200

PMid:12748183

14. Palumbo, S. L.; Memmott, R. M.; Uribe, D. J.; Krotova-Khan, Y.; Hurley, L. H.;

Ebbinghaus, S. W. Nucleic. Acids. Res. 2008, 36, 1755-1769.

http://dx.doi.org/10.1093/nar/gkm1069

PMid:18252774 PMCid:PMC2330228

15. Gabelica, V.; Baker, E. S.; Teulade-Fichou, M. P.; De Pauw, E.; Bowers, M. T. J. Am. Chem. Soc. 2007, 129, 895-904.

http://dx.doi.org/10.1021/ja065989p

PMid:17243826

16. Li, H. H.; Liu, Y. Q.; Lin, S.; Yuan, G. Chem-Eur. J. 2009, 15, 2445-2452.

http://dx.doi.org/10.1002/chem.200801922

PMid:19156807

17. Rosu, F.; Gabelica, V.; Shin-ya, K.; De Pauw, E. Chem. Commun. 2003, 2702-2703. http://dx.doi.org/10.1039/b309394h

18. Shin-ya, K.; Wierzba, K.; Matsuo, K.; Ohtani, T.; Yamada, Y.; Furihata, K.; Hayakawa, Y.; Seto, H. J. Am. Chem. Soc. 2001, 123, 1262-1263. http://dx.doi.org/10.1021/ja005780q

19. Agarwal, T.; Roy, S.; Chakraborty, T. K.; Maiti, S. Biochemistry-us. 2010, 49, 8388-8397. http://dx.doi.org/10.1021/bi1005927

PMid:20712380

20. Chakraborty, T. K.; Arora, A.; Roy, S.; Kumar, N.; Maiti, S. J. Med. Chem. 2007, 50, 5539-5542.

http://dx.doi.org/10.1021/jm070619c

PMid:17927166

21. Kaiser, M.; De Cian, A.; Sainlos, M.; Renner, C.; Mergny, J. L.; Telaude-Fichou, M. P. Organic \& Biomolecular Chemistry 2006, 4, 1049-1057.

http://dx.doi.org/10.1039/b516378a

PMid:16525549 
22. Kang, H. J.; Park, H. J. Biochemistry-us. 2009, 48, 7392-7398.

http://dx.doi.org/10.1021/bi9006836

PMid:19496619

23. Liu, Y. Q.; Zheng, B.; Xu, X. J.; Yuan, G. Rapid Commun. Mass. Sp 2010, 24, 3072-3075.

http://dx.doi.org/10.1002/rcm.4730

PMid:20872641

24. Teulade-Fichou, M. P.; Carrasco, C.; Guittat, L.; Bailly, C.; Alberti, P.; Mergny, J. L.; David, A.; Lehn, J. M.; Wilson, W. D. J. Am. Chem. Soc. 2003, 125, 4732-4740.

http://dx.doi.org/10.1021/ja021299j

PMid:12696891

25. Zhang, Q.; Cui, X. J.; Lin, S.; Zhou, J.; Yuan, G. Org. Lett. 2012, 14, 6126-6129.

http://dx.doi.org/10.1021/ol302918f

PMid:23210628

26. Marques, M. A.; Doss, R. M.; Urbach, A. R.; Dervan, P. B. Helv. Chim. Acta 2002, 85, 4485-4517.

http://dx.doi.org/10.1002/hlca.200290024

27. Li, H.; Yuan, G.; Du, D. J. Am. Soc. Mass. Spectr 2008, 19, 550-559.

http://dx.doi.org/10.1016/j.jasms.2008.01.012

PMid:18313939

28. Pierce, S. E.; Kieltyka, R.; Sleiman, H. F.; Brodbelt, J. S. Biopolymers 2009, 91, 233-243.

http://dx.doi.org/10.1002/bip.21130

PMid:19117031 PMCid:PMC2725001

29. Monchaud, D.; Allain, C.; Bertrand, H.; Smargiasso, N.; Rosu, F.; Gabelica, V.; De Cian, A.; Mergny, J. L.; Teulade-Fichou, M. R. Biochimie 2008, 90, 1207-1223.

http://dx.doi.org/10.1016/j.biochi.2008.02.019

PMid:18343231

30. Gabelica, V.; Rosu, F.; De Pauw, E. Anal. Chem. 2009, 81, 6708-6715.

http://dx.doi.org/10.1021/ac900785m

PMid:19601639 